\title{
A Contradiction in Nature: The Attitude Toward Nature and Its Implications in James Thomson's "The Seasons"
}

\author{
CODY FRANCHETTI*
}

\section{Introduction}

The attitude toward nature in James Thomson's The Seasons has not been duly noted by literary commentators. Instead, the reception of The Seasons in modern literary criticism has focused on all sorts of aspects, ranging from visual imagery, to "dislocation, deformity and renewal." ${ }^{1}$ However, when nature as a theme in the poem has been tackled, critics have favored its religious implications-specifically, those pertaining to the historical period in English literature, as well as a number of hypotheses about Thomson's own relation toward god-over Thomson's conception of nature on its own terms. Furthermore, none has, in my view, concentrated enough on the most emblematic characteristic of The Seasons: its unresolved stance toward the natural and its strongly polarized attitude toward it. The aim of this essay is to examine these inconsistencies in order to reveal what they tell us about the period's changing perspectives, to place The Seasons' reception of the natural in the history of eighteenth-century literature, and to uncover the implications and fertile consequences of Thomson's view of nature-which spill into para-literary domains.

After a success that endured into the early nineteenth century, The Seasons' popularity declined sharply: the poem was relegated to the dustbin of those well crafted but antiquated works of the eighteenth century, which became significant only insofar as they were a springboard for the early Romantic generation - the first "moderns." Then, in the latter part of the twentieth century, a number of articles and monographs appeared with the intent to re-evaluate The Seasons, while on the other hand, other critics sought to disparage it further. It shall become apparent that both attempts were often dictated by either extraneous or tendentious motivations, which exaggerated or diminished one aspect or another in Thomson's work-both to the latter's detriment. A frequent

* Cody Franchetti, Graduate School of Arts and Sciences, Columbia University, New York. E-mail: history@codyfranchetti.com.

${ }^{1}$ Ralph Cohen, The Unfolding of the Seasons (Baltimore: The John Hopkins Press, 1970), ch. IV. 
criticism levied against Thomson was his heterogeneous treatment of many themes in his poem: Reuben Brower, for example, has faulted Thomson for lacking a "unifying vision active in separate descriptions." " But in response to Brewer it is appropriate to point out that if the differing perspectives that Thomson manifests may be a formal problem from the literary point of view, they remain a most interesting feature that ought to be evaluated beyond the preoccupations of a uniform poetic vision: they are the result of the eighteenth century's multifarious currents and therefore not necessarily imputable as a flaw in Thomson's poetry, and, more importantly, Thomson's contradictions turn out to have had fertile consequences. Consequently, Thomson's supporters have also missed the mark by not confronting the crucial role of nature in his poem in its purely literary, historical locus.

\section{Society: Man's Accomplishment and Man's Demise}

I shall mainly concentrate on Autumn, for it is in Autumn that we find the most compelling passages with contrasting stances that reveal Thomson's fluctuating attitude toward nature. Fall also seems to be the season that Thomson envisions as being a sort of fulfillment of the year's cycle: “... autumnal months thus transmit / Those full, mature, immeasurable stores / That waving round, recall my wand'ring song." 3 These lines are preceded by a brief allusion to each of the other seasons' characteristic, none of which is altogether favorable: "Pensive Winter" (143), "gaudy Spring" (146), "Summer ... an arid waste" (147), evince that probably Thomson found autumn to be the most congruous season, which is interesting considering that he originally published Winter in 1726 as a standalone poem, without the intention of writing about other seasons until Winter's resounding success induced him to keep writing a season a year until in 1730 The Seasons appeared.

Before we look at Thomson's inconsistent attitude toward nature, which I think reveals with greatest clarity the aporia in The Seasons' poetic ethos-and therefore both the work's greatest merits and defects-I should first like to point out an interesting oxymoron, which occurs at the beginning of Autumn, when Thomson extols industry.

These are thy blessings INDUSTRY! Rough pow'r!

Whom labour still attends, and sweat, and pain;

Yet the kind source of ev'ry gentle art,

And all the soft civility of life

(III. 43-46)

Rude labor is a civilizing process: it begets sophistication. One may retort that Thomson's view is counter-intuitive, since it is often indolence that induces man to occupy himself with "ev'ry gentle art," but Thomson sees the latter as a direct result of toil-and rough toil at that! Thomson is praising work's virtues, with an eminently common-sense British attitude: industry is viewed as a tonic for "savage" profligacy,

\footnotetext{
${ }^{2}$ Quoted in ibid., 1.

${ }^{3}$ (III. 148-50).
} 
and yet, "rough pow'r" is "the kind source of "ev'ry gentle art." In other words, according to Thomson brutality begets gentility. The contradiction is increased in the following passage, where Thomson traces the human past from a savage, slothful, barbarian age, which through industry leads to the development of modern, social institutions, which "rous'd him [man] from his miserable sloth" (73). But Thomson goes further to add that industry not only is a civilizing force but also what drove the invention of science:

The life-refining soul of decent wit:

Nor stopped at barren bare necessity;

But still advancing bolder, led him on

To pomp, to pleasure, elegance and grace;

And breathing high ambition through his soul,

Set science, wisdom, glory, in his view,

And bade him be the Lord of all below.

(III. 89-95)

This view is in direct contrast to Classical poetry. In Ovid's Metamorphoses, work was associated with the "iron age," an age of grief and grueling exertion in a declassed world. The opposite is true of The Seasons, where Thomson is clearly a child of the Enlightenment inasmuch as he believes in the increasing perfection of society and in the telos of progress. Thomson's poem is also clearly anchored in the ethics of English Augustan poetry, which continually questioned whether the individual or society was paramount.

However, as we have seen in the preceding two excerpts, there is a troubling negative implication: the boon of the modern age has been wrought out of rude, exhausting work. John Barrell has commented on this double standard:

On the one hand, the history of society has been one of decline, from an age of innocence to a period of luxury and strife; on the other, society has progressed, by the development of political and judicial institutions, of the mechanic and polite arts-and particularly in Britain-to a point of perfection. ${ }^{4}$

Thus, Thomson's attitude is equivocal also toward civility (the "polite arts"). In Winter, as he describes how an evening is spent indoors, in turn by philosophers, peasants, and townspeople, Thomson exhibits contempt for the personages which populate high society:

The glitt'ring court effuses ev'ry pomp;

The circle deepens: beam'd from gaudy robes,

Tapers, and sparkling gems, and radiant eyes,

A soft effulgence o'er the palace waves:

While, a gay insect in his summer shine,

The fop, light-flutt'ring, spreads his mealy wings.

(IV. 640-45)

${ }^{4}$ John Barrell, English Literature in History: An Equal, Wide Survey (New York: St. Martin's Press, 1983), 54. 
Barrell's point is a good one but he disregards Thomson's more important contradiction - his relationship to nature — which, we shall see, is even more inconsistent—and absorbing. However, this conflict has not gone unnoticed by all critics: Patricia Spacks speaks of “Thomson's pattern of contrasts and of kinships between the human and natural world." Spacks's book concentrates mostly on The Seasons' relationship between vision and meaning; and her chapters on Thomson are a re-evaluation of his poetic despite its "amalgam of different points of view has justified attacks on the The Seasons for its lack of intellectual unity." 6 But this "lack of poetical unity" is a significant contrasting poetical ethos: Thomson's inconsistencies evince a poiesis that oscillates between the Enlightenment and proto-Romanticism. Let us thus look at the theme of nature in The Seasons and the poet's relationship to it-what is probably the most conspicuous subject of the poem.

\section{The Lure of Nature}

The first half of the eighteenth century saw literary circles of every nation embattled in endless debates about nature's role in poetical invention. In Britain, Addison had declared nature to be of higher import and consequence than art, but he also stated that the latter could attain perfection by finding its inspiration in nature:

there is something more bold and masterly in the rough, careless strokes of Nature, than in the nice touches and embellishments of art. ... For this reason we always find the poet in love with a country life, where Nature appears in the greatest perfection, and furnishes out all those scenes that are most apt to delight the imagination. ${ }^{7}$

Indeed, even Thomson thought so: "I know no subject more elevating, more amusing, more ready to awake poetical enthusiasm, the philosophical reflection, and the moral sentiment, than the works of Nature." 8

The Seasons displays a fascinating inconsistency toward the natural. At times the poem goes well beyond the edifying views of nature advocated by Addison or Thomson himself; the depiction of nature in The Seasons far exceeds the elevating, mannered standards of his time. On the other hand, Thomson's description of nature is at times stilted and prey to commonplace, eighteenth-century preciosity.

Autumn best displays this inconsistency, because the clashing passages are in closest proximity. An unusual and overwhelming description of natural phenomena appears early in Autumn. In the following verses, the sheer awe that nature generates is striking.

At first the groves are scarcely seen to stir

Their trembling tops; and a still murmur runs

\footnotetext{
${ }^{5}$ Patricia Meyer Spacks, The Poetry of Vision (Cambridge: Harvard University Press, 1967), 4.

${ }^{6}$ Ibid., 35.

${ }^{7}$ Quoted in Spacks, The Poetry, 13.

${ }^{8}$ Thomson's preface to Winter (1726), when it was first published as a single poem; also quoted in Spacks, The Poetry, 13.
} 


\begin{abstract}
Along the soft-inclining fields of corn.
But as the aerial tempest fuller swells,

And in one mighty stream, invisible,

Immense, the whole excited atmosphere,

Impetuous rushes o'er the sounding world;

Stain'd to the root, the stooping forest pours

A rustling show'r of yet untimely leaves.

High-beat, the circling mountains eddy in,

From the bare wild, the dissipated storm,

And send it in a torrent down the vale.

Expos'd, and naked, to its utmost rage,

The billowy plain floats wide; nor can evade,

Tho' pliant to the blast, its seizing force;

Or whirl'd in air, or into vacant chaff

Shook waste. And sometimes too a burst of rain,

Swept from the black horizon, broad, descends

In one continuous flood....
\end{abstract}

(III. 313-32)

This portentous illustration is introduced by a powerful synesthesia, one of the very few in the entire poem ("a still murmur runs / Along the soft-inclining fields of corn"). This kind of metaphoric construction is referred to as a "complex synesthesia," since three sensorial domains - touch, hearing, sight - are both engaged simultaneously and equalized, as the different senses involved are made almost indistinguishable.

What follows-the rapture over the immensity of nature, the enchantment of the sights, and the unruly impetuosity of natural phenomena-evinces a sensibility that is foreign to the improving descriptions commonly found in less inspired depictions of nature of the period. The passage is a perfect example of what Patricia Spacks called "a poetry of sensitivity," "which is an aspect of the Romantic spirit. She is therefore quite right in pointing out that:

It would be a mistake to assume that poetry waited upon criticism before becoming, in fact, "expressive." When one examines the poetry of the eighteenth century, after its opening decades, that poetry which Coleridge, on the whole, patronized or actively scorned, it seems surprising that the view Coleridge articulated had to wait so long to find statement: it is implied by a good deal of the verse written between 1726 and 1800, which manipulates imagery in elaborate ways to express emotion to stimulate "associated thoughts" or to sum up and emblemize multiplicity or to convey the "spirit" of its author. $^{10}$

In other words, the Romantics merely formalized what was already in the "poetic atmosphere" well before them. In fact, in the passage above Thomson foreshadows a Wordsworthian sensitivity to nature's elemental attraction.

\footnotetext{
${ }^{9}$ Spacks, The Poetry, 4.

${ }^{10}$ Ibid., $10-11$.
} 
There is another modern aspect in Thomson's passage that is of particular interest. The way the storm is depicted above, as well as the overall scenery, follows the precepts of "Of Light and Shade" laid in William Hogarth's Analysis of Beauty (1750), to which Hogarth dedicated an entire chapter of his celebrated treatise.

Thus, as by object growing still fainter, we judge of distances in prospects, so by the decreasing noise of thunder we form the idea of its moving further from us. And, with regard to their similitude in beauty, like as the gradating shade pleases the eye, so the increasing or swelling note, delights the ear.

I have called it in the retiring shade, because by the successive, or continual change in its appearance, it is equally instrumental with converging lines, in shewing how much objects, or any parts of them, retire or recede from the eye ... frequent deceptions happen to the eye on account of deficiencies in this shade: for if the light chances to be so disposed on objects as not to give this shade its true gradating appearance, not only spaces are confounded, but round things appear flat, and flat ones round. ${ }^{11}$

Thomson's autumnal deluge with its play of light and shadow, its almost pictorial blotches of light and dark, so closely adheres to these principles, that it seems to have been conceived after a thorough reading of Hogarth's text, which of course is impossible. This is an indication of Thomson's presaging aesthetic intuition: Hogarth's treatise erupted on both the English and European eighteenth-century aesthetics as a revelation, providing new cues for ideals of beauty that lay ahead. The Analysis of Beauty dismantled old standards of "good taste" — the canons of Classical beauty — and fixed new ones for it. Beauty's attributes were no longer symmetry, regularity, logic, proportion, but rather, the exciting interplay of twisted and straight, strange and normal, hideous and lovely, dysmorphic and eumorphic, and, sometimes, according to Hogarth, beauty even lay in the grotesque. This cardinal text had an enormous influence and its effect can be ascribed to the widest assortment of artists, of all of whom are considered heralds of modernity: In England, from Burke to Swift, to Sterne, to Walpole and Dickens; in Germany, from Lessing to Goethe-and even Rilke, who in his second Duino Elegy wrote unambiguously, "Beauty is but the beginning of the horrific"12; in France, from Diderot to Baudelaire; and in modern art criticism, from Roger Eliot Fry to Gombrich.

But Thomson's relationship to nature is not at all exemplified by the extract I have been discussing. Ralph Cohen, who argued against Reuben Brower's view of The Seasons' lack of unified vision, thought of Thomson's poem mainly as “a religious didactic poem"13 and implied a homogeneous treatment of nature: "Thomson's precision, achieved by converting periphrasis to a combination of personification and scientific classification, interpreted nature accurately, scientifically and humanistically..."14 But Cohen's view of Thomson's consistent description of nature is inaccurate: in a

\footnotetext{
${ }^{11}$ William Hogarth, The Works of William Hogarth, vol. 2 (London: Rob Scholey, 1812), 98.

${ }^{12}$ [Das Schöne ist nich als das Schrecklichen Anfang].

${ }^{13}$ Cohen, The Unfolding, 3.

${ }^{14}$ Ibid., p. 229.
} 
later passage, Thomson's description of the harvest does not elevate itself much above commonplace platitudes.

As thus they brighten with exalted juice,

Touch'd into flavour by the mingling ray;

The rural youth and virgins o'er the field,

Each fond for each to cull th' autumnal prime,

Exulting rove, and speak the vintage nigh.

Then comes the crushing swain; the country floats,

And foams unbounded with the mashy flood;

That by degrees fermented, and refin'd,

Round the rais'd nations pours the cup of joy:

The claret smooth, red as the lip we press

In sparkling fancy, while we drain the bowl;

The mellow-tasted burgundy; and quick,

As is the wit it gives, the gay champaign.

(III. 692-704)

This hackneyed passage portrays nature's autumnal guise artificially; its affected images ("pour the cup of joy") and mannered descriptions ("red as the lip we press") are prey to a vacuous preciosity ("foams unbounded with the mashy flood"); the picture of the harvest and the excitement it triggers is contrived at best ("In sparkling fancy, while we drain the bowl ... As is the wit it gives, the gay champaign."). Throughout, the passage is plagued by didacticism or abstract descriptivism.

That this stale depiction is preceded by one of the most startling and innovative descriptions of nature in all The Seasons is all the more surprising. Just fifty lines above, Thomson engages in a remarkably modern conception of nature when he yearns to surrender to her spell: "In this glad season, while his sweetest beams / The sun sheds equal o'er the meeken'd day; / Oh lose me in the green, delightful walks." ${ }^{15}$ His petition "Oh lose me..." is so affecting and startling that there is almost a need for an exclamation mark at its end. And surely, Thomson lavishes a wealth of exclamation marks as his entreaty gains force and becomes more arresting and full of implication at the end of Autumn: "Oh NATURE! all-sufficient! over all! / Inrich me with the knowledge of thy works! / Snatch me to heaven ...”. ${ }^{16}$ In these verses Thomson's desire for a communion with nature reaches its zenith, as he arrantly renounces the ideals of the Enlightenment, and manifests a burning will for a loss of consciousness through and within nature.

There is an eminent antecedent to this singular wish for the renunciation of consciousness while being engulfed in nature: it is in Andrew Marvell's The Garden.

The mind, that Ocean where each kind

Does straight its own resemblance find;

Yet it creates, transcending these,

${ }^{15}$ (III. 651-53).

${ }^{16}$ (III. 1350-53). 
Far other worlds, and other seas;

Annihilating all that's made

To a green thought in a green shade.

(43-48)

Like Thomson's "Oh lose me in the green delightful walks," Marvell, too, insinuates that nature has the power and lure to infuse the desire to lose awareness, and, as Thomson, who also extols reason, Marvell's precedes his yearning for a thought outside this world, with a strong, almost Lockean declaration of the powers of consciousness: "The mind, that Ocean where each kind / Does straight its own resemblance find." In a rather Platonic stance, Marvell is saying that our mind finds correspondence of its forms in the physical world. And yet, all rationality is abandoned at the sight of "the natural"instantly and gleefully.

In his brief but foundational treatise on Romantic aesthetics, On Naive and Sentimental in Literature (1795), Friedrich Schiller theorized that ancient, Classical literature was "naïve" in that it was spontaneous, because man lived in nature, in singular unity with it, and there was no scission between human life and the natural world. With the advent of the "modern" age, as man detached himself from nature and any harmony with it vanished, "the sentimental" surfaced in literature and poetry: man now aspired to that lost perfection, when his life and the natural were unintelligible. The aspiration for an irretrievable fullness, according to Schiller, is "the sentimental," or, the emergence of modernity. ${ }^{17}$ This insightful concept of the changing poetic ethos through the eighteenth century is, I think, an idea that is valid for all European literature. Thus, a trajectory of the Schillerian "sentimental" sensibility may be traced in English literature from Marvell to Wordsworth-Marvell representing the emergence of this yearning for a lost communion with nature; Thomson being an important station, perfectly articulated by in Spack's formula of "poetry of sensitivity"; and Wordsworth, an obvious point of arrival:

The world is too much with us; late and soon

Getting and spending, we lay waste our powers:

Little we see in Nature that is ours

...

For this, for everything, we are out of tune;

It moves us not.-Great God! I'd rather be

A Pagan suckled in a creed outworn;

So might I, standing on this pleasant lea,

Have sight of Proteus rising from the sea;

Or hear old Triton blow his wreathed horn. ${ }^{18}$

Wordsworth's disenchantment with the world-a world that has lost any contact with nature-and his longing for a communion with nature, now consigned to oblivion and

\footnotetext{
${ }^{17}$ See Friedrich Schiller, On the Naive and Sentimental in Literature (Manchester: Carcanet Press, 1983).

${ }^{18}$ Untitled poem written in 1807 by William Wordsworth, The Collected Poems of William Wordsworth (London: Wordsworth Editions, 1994), 307.
} 
therefore impossible, make his verses an archetypal example of Schiller's idea of "the sentimental" in all it entails, all it represents, and everything it is a result of.

\section{Haydn's "The Seasons"}

Lastly, I should like to look at Haydn's great oratorio The Seasons, which is based on Thomson's poem, for the merits of the music are also in part, as we shall see, what have often been misunderstood as defects in Thomson's The Seasons. Robbins Landon, the compiler of Haydn's preeminent biography, a monument of scholarly work in five volumes, which contains a massive amount of evidence well beyond the realm of Haydn's life and music, gives clear evidence of The Seasons' enduring success: “Thomson's poem was, particularly in the 1790 's, enjoying not only continuous but if anything an increased popularity: during Haydn's years in England, several handsomely illustrated editions of The Seasons were issued: two came out in 1793, another one (with illustrations by Conrad Metz) in 1794, and in 1797 after Haydn had left England for the last time, Francesco Bartolozzi engraved the illustrations, after designs by William Hamilton for an ambitious luxury folio edition. Even Henry Fuseli could not resist the poem and provided two plates for the 1797 edition." ${ }^{19}$ The idea to adapt Thomson's poem into a libretto for an oratorio came to Baron Gottfried van Swieten, who had also written the libretto for Haydn's other great and better known oratorio, The Creation, which had premiered in 1798. Van Swieten was an active patron of the musical arts in Vienna; he had championed Mozart twenty years earlier when the composer had permanently settled there in late 1781. Van Swieten had freely adapted parts of the Book of Genesis for the libretto of The Creation; and after its resounding success, Swieten looked for another subject to tempt Haydn to write another oratorio. The Seasons, which as we've seen was held in high regard, was chosen quite rightly according to Landon because "there is a strong feeling of deism in the poem, and this aspect probably appealed to Gottfried van Swieten, whose choice of the subject for Haydn's music was, however, motivated rather by the descriptions of nature which, the Baron no doubt rightly considered, would fire the composer's imagination."20

And fire it did: The Seasons is one of the greatest oratorios of the eighteenth century, and stands along with Haydn's own The Creation, Händel's Messiah, and other masterworks of the genre. In fact, it is ironic that later, after the mid-nineteenth century, Thomson's name would be remembered by virtue of Haydn's oratorio. But those whose only exposure to Thomson was through Swieten's adaptation have a experienced a grossly depreciated version: Swieten's libretto was much criticized for being simplistic and deficient; furthermore, his libretto was written in German, which he then retranslated into English for the performances in England; but Swieten's knowledge of English was "not up to the task, and both the French and English translations are very

\footnotetext{
19 Howard Chandler Robbins Landon, Haydn: Chronicle and Works, vol. 5 (Bloomington: Indiana University Press, 1977), 93.

20 Ibid., 94.
} 
unhappy."21 Surely, a retranslation from the original to another language and back would eliminate much of the bloom of any work: if the German version alone was deficient, a translation into English based on Swieten's version could only have had an exiguous outcome at best. Nevertheless, Swieten's first adaptation accomplished its demands, since it did indeed "fire” Haydn's imagination.

The oratorio was first performed at Prince von Schwarzenberg's palace on April 24, 1801 for a select but mixed audience, but it was soon performed all over Europe. The contemporary reviews are extremely interesting, for even in van Swieten's shorn adaptation they successfully perceived the heterogeneous treatment of the subject and found it a source of value: the review of the first performance of Haydn's The Seasons outside the Austrian empire shows this unequivocally. The Allgemeine Musikalische Zeitung, the foremost musical publication in Germany in the nineteenth century, ${ }^{22}$ reviewed the performance in Leipzig in November 1801 as follows:

The effect of the work on a large, mixed audience must be very lively, if only because of he inexhaustible richness and exceptional variety of the content and its treatment, which in itself reaches extremes, and though which every listener, however educated (in music) he may or may not be, receives something dear to him. ${ }^{23}$

Later, in the same review, the libretto and its effect on the music-and therefore on the greater artistic value-is assessed with considerable acumen.

The composer had obviously had less of a share in the jesting than did the writer of the text, who gave the tools out of which the former fashioned the music. The whole plan is mistaken: peasants $\operatorname{sing}^{24}$ the most sublime and the most ridiculous, rise to lyrical heights and sink to platitudinous depths, and so forth.... It may be, all the same, that the intellect, and with it the inseparable and, in many of life's situations, dangerous partner, the pure taste, may object seriously to certain passages.

It may be that one damns the treatment of the text, especially in the recitatives, and altogether protest against the whole undertaking in which things are described that actually cannot be described: nevertheless the work has, and will continue to have, incomparable beauties, wonderfully and grandly produced passages and tone-paintings; true artistic diligence, especially in the choruses, which manifests itself at the same time in an entirely new accompaniment. Because of all of this, the work will be distinguished for all time. The music in The Seasons pushes to the last degree that which belongs in the realm of the pictorial by using the associations of ideas. ${ }^{25}$

The review is long and detailed; but the two selections from it are enough to show that the "contradiction in nature" in Thomson's poem was discussed, and, the first part observed that the heterogeneous treatment, just as this essay has sought to demonstrate,

21 Ibid., 95.

22 Among its contributors were Schumann, Liszt, E. T. A. Hoffmann, and Hanslick.

${ }^{23}$ Landon, Haydn, 185.

24 Swieten's libretto employed for dramatic purpose peasants as main characters, who speak (sing) Thomson's descriptions.

25 Ibid., 186. 
was not a failing. There is in fact a fascinating similarity between the contemporary reviews of Haydn's The Seasons and the criticisms raised by recent literary critics about Thomson, except that what our modern critics saw as deficiencies, the first reviewers of the oratorio saw as virtues.

Granted, the review refers to Swieten's libretto, which we have determined to be but a pale rendition of the original, and as such, it may be countered that there is no relation between Thomson and Haydn: to show that that is not so, I should like to relate an anecdote.

At the end of the eighteenth century, Johann Wolfgang von Goethe saw a representation of Christopher Marlowe's Doctor Faustus in a puppet theatre in Germany. The legend of Faust had been dramatized by the great English playwright for the first time in $1592^{26}$ Marlowe's dramatization had been preserved in Germany and it had permeated popular consciousness (the story of the scholar's pact with the devil, was, after all, an ancient German legend). What Goethe saw was merely a crude, vulgar rendering of Marlowe's play. Nevertheless, Goethe, through the artistic and hermeneutical gazewhich is so inscrutable as can only be fitly called preternatural-sensed the greatness that lay within that base residuum, re-cast the legend in his own terms, and broadened its metaphysical resonance. This fascinating, magical ability of artistic thought to travel through a frayed guise is, I think, what enables Haydn's The Seasons to share similarities with Thomson's own The Seasons even via the poor transposition of van Swieten.

\section{A Contradiction in Nature}

I have sought to examine The Seasons' uneven treatment of nature and to show the implications that its contradicting stance evinces. We have seen that if Thomson's disparate depictions of nature might be problematic from a formal point of view, they are, from the point of view of content, extremely fecund: firstly, they evince an aesthetic shift that had already started well before 1730, and that was to continue progressively until the Romantic age - the abandonment of rationality, that cardinal preoccupation of the enlightenment and the ideal that it was the paramount faculty of man; secondly, in the descriptions where Thomson displays an unusual, susceptible sensibility for natural phenomena, as well as the desire to escape a world where man is too distant from nature, thus prefiguring Schiller's concept of "the sentimental," Thomson has enduring moments of evident proto-Romantic flavor (The Seasons in this respect, may be seen as the midpoint in the arc of changing disposition of the spirit from "cogito ergo sum" to "cogito ergo sentio"); thirdly, by manifesting trends and tendencies that other, more established harbingers of Romanticism, such as Hogarth and Wordsworth, were to develop further in the following decades, Thomson should be reassessed-historically—as being indefeasibly beyond a mere exponent of English Augustan poetry.

\footnotetext{
26 The exact date of its writing is unknown: the play was registered in 1592 into the Stationers' Register and first published in 1604, eleven years after Marlowe's death; as many as 25 performances are known to have been staged between 1594 and 1597.
} 
I also hope to have shown, through the example of Haydn's oratorio, that the singularities I described above contributed to make Thomson's poem speak to the early Romantic generation across various nations. After all, by the time of Haydn's premiere, in Germany Hölderlin had already written his greatest poems and was about to descend into forty years of madness; Novalis had just died in March, and his Hymns to the Night (1800) with its astonishing lyricism and depiction of the caducity of man in the face of nature redefined German Romantic poetry; in England, Wordsworth and Coleridge had published their Lyrical Ballads (1798) and unofficially inaugurated English Romanticism. And so, that Thomson's poiesis had currency in such different cultural and aesthetic settings than his own ought to gain us an appreciation for The Seasons that has escaped far too many literary critics.

There is something unequivocally "modern" about The Seasons, a work born out of the eighteenth century - a century so strange to our eyes, so modern, yet at once so remote. It is in the optic of this unruly multifariousness, in fact, in this inherent contradiction in nature of the eighteenth century, that I think we ought to view Thomson's own "contradiction in nature" — its convulsions toward modernity-as an avowal of merits that a "uniformity in nature" would unquestionably lack. 